\title{
Implementation of the Use of Neuroscience-Based Arabic Learning Media on Students: A Case Study at Vocational High School Muhammadiyah 3 Yogyakarta
}

\author{
Mohammad Jailani \\ Universitas Ahmad Dahlan Yogyakarta \\ mohammad2007052014@webmail.uad.ac.id \\ Hendro Widodo \\ Universitas Ahmad Dahlan Yogyakarta \\ hwmpaiuad@gmail.com
}

\begin{abstract}
This study aimed to analyze neuroscience-based Arabic learning media at SMK Muhammadiyah 3 Yogyakarta. Implementation to students so they could memorize mufrodat and practiced mubadasab in Arabic. The type of research used in this research was qualitative. The research subjects were teachers and students. Determination of research subjects was done by using purposive sampling. Data collection techniques were carried out using interview, observation, and documentation methods. The validity of this research data used triangulation. Data analysis used the Miles and Huberman model, namely by data reduction, data display, and conclusion drawing/verification data. The results of the study of neuroscience-based Arabic learning media that were applied in the classroom were identifying students with five (mufrodat). In addition, each student memorized five (mufrodat), practiced (mubadasab) with his/her classmates, and directed by the teacher who responded to the student's brain. Learning media, in the form of videos in which it was more directed to the students' brains became the focus of learning Arabic. The Arabic learning video contained mufrodat material that was easy for students to memorize and practice. Facilitating students in memorizing mufrodat covered maharah qiro'ah, kitabah, istima', and kalam. It meant, students could read Arabic mufrodat or quwa'id correctly; they could write Arabic mufrodat or quwa'id with imla'; and they could listen to mufrodat correctly. Continuously, students could apply mubadasab fluently.
\end{abstract}

Keywords: Learning media; Arabic; neuroscience; students 


\begin{abstract}
Abstrak
Penelitian ini bertujuan menganalisis media pembelajaran bahasa Arab berbasis neurosains di SMK Muhammadiyah 3 Yogyakarta. Implementasi kepada siswa agar bisa menghafal mufrodat, dan praktek muhadasab bahasa Arab. Jenis penelitian yang digunakan dalam penelitian ini adalah kualitatif. Subjek penelitian adalah kepala sekolah, 3 orang guru, 20 siswa. Penentuan subjek penelitian dilakukan dengan teknik purposive sampling. Teknik pengumpulan data dilakukan dengan menggunakan metode wawancara, observasi, dan dokumentasi. Keabsahan data penelitian ini menggunakan triangulasi. Analisis data menggunakan model Miles dan Huberman, yaitu dengan data reduction, data display, dan data conclusion drawing/verification. Hasil penelitian media pembelajaran bahasa Arab berbasis neurosains yang diterapkan di kelas adalah mengidentifikasi siswa dengan lima (mufrodat). Di lanjut masing-masing siswa menghafal lima (mufrodat), dan praktek praktek (mubadasab) bersama teman sebangkunya. dengan diarahkan oleh guru yang merespons terhadap otak siswa. Media pembelajaran, berupa video yang di dalamnya lebih mengarah kepada otak siswa sebagai focus belajar bahasa Arab. Video pembelajaran bahasa Arab di dalamnya berisi materi mufrodat yang mudah dihafal dan dipraktekkan oleh siswa. Memudahkan siswa dalam menghafal mufrodat yakni dalam maharah qiro'ah, kitabah, istima', dan kalam. Artinya, siswa mampu membaca dengan benar lafadz Arab, siswa mampu menulis lafadz. Arab atau buruf Arab dengan imla', siswa mampu mendengarkan mufrodat dengan benar, dan dilanjut siswa mampu mengaplikasikan mubadasah dengan fasih.
\end{abstract}

Kata kunci: Media pembelajaran; bahasa Arab; neurosains; peserta didik

\title{
Introduction
}

Learning Arabic will not be separated from the approach of material, methods, learning media, and learning evaluation. Discussing learning media, according to Nurul, learning media is a set of subject matter materials that are arranged coherently and systematically and display competencies that students will master in learning activities. ${ }^{1}$ More than that, learning materials are a very decisive component for the achievement of learning objectives. Completely and systematically arranged learning materials can create effective and efficient

1 Nuril Mufidah Umm Saidah, Saidna Zulfiqar Bin-Tahir, “Arabic Teachers' Competence: A Case of Madrasah Schools in Maluku,” Ijaz Arabi 1, no. 21 (2018): 1-9. 
learning process. $^{2}$ The quality of learning media is one of the determining factors for the learning process to achieve its goals. ${ }^{3}$

Preparing and making learning media is certainly not an easy job. ${ }^{4}$ The learning media are findings that determine the competencies to be achieved and possessed by students at the end of the activity or after the learning process takes place. Teaching materials are selected based on the objectives to be achieved, and according to the needs, interests, and learning talents. Implementation of language teaching materials refers to the needs of teachers and learners as the sources of language input that are useful for maximizing learning outcomes in ways designed to promote language teaching materials. ${ }^{5}$

So far, the problem that occurs in SMK Muhammadiyah 3 Yogyakarta is that no learning media is suitable for student learning. Learning Arabic is one of the local content subjects that is required by the Ministry of Religion General of Islamic Education and is one of the requirements for students' graduation by the Directorate General of Primary and Secondary Education for Muhammadiyah Regional Leaders of Yogyakarta City. However, it is applied in the implementation of learning this subject, it is avoided by students and the lack of interest in learning. Students have difficulty responding to Arabic learning delivered by educators. The absence of mentoring and focus of educators with good learning methods. ${ }^{6}$ On the one hand, students cannot read the Qur'an, and there is no learning that is relevant to the way students think and learn, just an example of conventional module-based learning or ordinary teaching materials.

So far, research on learning Arabic have addressed and discussed the realms pertinent to the development of Arabic learning models based on

\footnotetext{
${ }^{2}$ Nuril Mufidah and Intan Izha Rohima, "Vocabulary Teaching For Arabic Intensive Class," (Ujss) Uniqbu Journal Of Social Sciences 5, no. 1 (2020): 55.

${ }^{3}$ Mohammad Jailani, Suyadi, and Betty Mauli Rosa Bustam, "Special Edition: Islamic Studies and the Challenges of the COVID-19 Pandemic," in Development of NeuroscienceBased Arabic Learning Media: Field Studies in Vocational High Schools During the Covid-19 Period, ed. Rohana Zakaria et al. (Malaysia: Selangor International Islamic University College (KUIS), 2021), 44-50.

${ }^{4}$ Nuril Mufidah et al., "Language Tutor Enrichment Model: A Pre-Learning Study on Shabahul Lughoh at Ma'had Sunan Ampel Al Aly," At-Ta'dib 13, no. 2 (2018): 50-61, doi:10.21111/at-tadib.v13i2.2650.

5 Zakiyah Arifa and Dewi Chamidah, "Development of Mid Map-Based Arabic Qawaid Teaching Materials for Higher Education Level," The International Journal of Artificial Organs 10, no. 6 (1987): 406-7, doi:10.1177/039139888701000618.

${ }^{6}$ Mohammad Jailani et al., "Development of Islamic Religious Education Learning Materials: Its Implications for Islamic Education," Al-Idara: Journal of Islamic Education 11, no. 1 (2021): 143-55.

${ }^{7}$ Rahadian Kurniawan, Musda Asmara, and H Hardivizon, "Arabic Language and the Concept of I'jaz Al-Qur'an (Critics to Louwis 'Awad's Thoughts) Awad)," Arabiyatuna: Arabic Journal5, no. 1 (2021): 161, doi:10.29240/jba.v5i1.2622.
} 
modules or teaching materials, conventional models, and student worksheets. ${ }^{89}$ Educators direct more to students only to explain, read, and write without alternative constructive learning strategies. ${ }^{10}$ The literature on relevant research is found in research undertaken by Ahmad 2020, in which his research examines the ineffectiveness of conventional learning techniques which are seen by students in fact as monotonous and boring, as a result of students being lectured by teachers or educators who are increasingly being taught. In the results of his research, the adopted solution is learning Arabic with the Questioning and Media Kahoot methods. The results of the research show that teachers as facilitators and content creators can add elements in the form of videos, images, and text and students can access them via smartphones or computers $^{11}$ The second similar study was reviewed by Fauzi 2020, in his research he stated that the use of Neuroscience in Arabic Curriculum Development Design, this research is more directed to the use of Neuroscience as the development of the Arabic language education curriculum in line with the problem that in the article, the functional use of the brain can affect the performance of the mind and the design of the teacher's thinking in implementing the Arabic curriculum. ${ }^{12}$ In the results of his research, he answered that the brain is an element of optimizing student learning and the brain is a substance in the Arabic language education curriculum. ${ }^{13}$ The real implications of the Arabic language problem center on the overall use of reason from the learner's brain. ${ }^{14}$ It ends with the findings of Nurul's 2020 research, that the learning process uses the lecture method, some students are too focused

8 Apri Wardana Ritonga et al., "Teaching Maharah Kalam on the Basis of Culture Using the Textbook 'Al-,,Arabiyyah Baina Yadaik' at the Middle School," Arabiyatuna: Arabic Journal5, no. 1 (2021): 1-22.

${ }^{9}$ Kurniawan, Asmara, and Hardivizon, "Arabic Language and the Concept of I'jaz AlQur'an (Critics to Louwis 'Awad's Thoughts)."

${ }^{10}$ Mohammad Jailani et al., "Strengthening the Neurolinguistic Approach in Learning: Case Study on Arabic Language Learning at Madrasah Aliyah,"Al-Thariqah Journal of Islamic Education 6, no. 1 (2021): 152-67.

11 Ahmad Fadilah Khomsah and Muhammad Imron, "Arabic Language Learning Through Collaborating Questioning Methods and Kahoot Media," Tarbiyatuna: Scientific Education Journal 5, no. 1 (2020): 99-118.

12 Fauzi Muhammad Ilfan, "Utilization of Neuroscience in Arabic Curriculum Development Design,” Arabiyatuna: Arabic Journal4, no. 1 (2020): 1, doi:10.29240/jba.v4i1.1095.

${ }^{13}$ Ibid.

14 Mohammad Jailani, Suyadi, and Dedi Djabedi, "Traveling the Traces of the Brain and 'Aql in the Qur'an from the Perspective of Neuroscience and Islamic Education in the Era of the COVID-19 Pandemic," Tadris: Journal of Islamic Education 16, no. 1 (2021): 1-19, doi:10.19105/tipi.v16i1.4347. 
on learning, students feel bored because teachers only use projectors, PowerPoint slides, and blackboards. ${ }^{15}$

Thus, based on previous research references, there has been no research that has raised neuroscience-based learning media. Learning with neurosciencebased learning media applied at SMK Muhammadiyah 3 Yogyakarta. Considering the literature facts and social facts from this study, the researcher assumes that the position of the researcher in this study is to be a novelty to previous research. Novelty on relevant research as a follow-up to get new findings in the research base. The novelty in this research can be said to be a follow-up to Fauzi's research as mentioned above regarding the use of neuroscience in the design of Arabic curriculum development, but in the Fauzi research, Neuroscience focuses on implications for the development of the Arabic language curriculum, while in this study neuroscience is intended as an implication as well as an alternative medium for learning Arabic, especially at SMK Muhammadiyah 3 Yogyakarta. The findings of this study will be explored in the form of a narrative in the results and discussion of this study. Explicitly in this study, the researchers described the implementation of the use of neuroscience-based Arabic learning media, because it makes it easier for students to learn, understand the material, memorize mufrodat and apply mubadasah practices. It provides new benefits for students because conventional learning models and module-based learning have been central to being implemented at SMK Muhammadiyah 3 Yogyakarta in prior.

The purpose of the study was to analyze neuroscience-based Arabic learning media at SMK Muhammadiyah 3 Yogyakarta. The research process started from the beginning of the new academic year 2021/2022 at the beginning of February. The reason for choosing SMK Muhamamdiyah 3 Yogyakarta as the research location was to find out the implementation of neuroscience-based language learning media. The research subjects were 20 students of class X (ten) TKJ. Researchers gave questionnaires to students related to neuroscience-based learning media. The effectiveness of this media could help the process of learning Arabic in SMK Muhammadiyah 3 Yogyakarta. The benefits of neuroscience media make it easier to learn Arabic, motivate students in learning, and cultivate students' talents and interests because it answers the problems that have occurred so far at SMK Muhammadiyah 3 Yogyakarta. Based on information from students, they have not been able to memorize mufrodat and launch muhadasah practices. Likewise, information from the teacher demonstrates that the teaching and learning process so far has not run optimally because students have not mastered Arabic well. So far, at SMK Muhammadiyah 3 Yogyakarta, the learning has

${ }^{15}$ Nurul Isnaini and Nurul Huda, "Development of Arabic Vocabulary Learning Media Based on My Happy Route Game," Al Mi'yar: Scientific Journal of Arabic and Arabic Language Learning 3, no. 1 (2020): 1, doi:10.35931/am.v3i1.156. 
been held based on conventional modules and models. Neuroscience-based Arabic learning media makes it easier for students to learn Arabic in terms of reading, writing, listening, and mubadasab. It helps students practice speaking (mubadasab) and learn grammar (quwaidul'Arabiyah) with the media as a means of communication and props by educators in conveying the material. Also. it overcomes the difficulties of students in learning Arabic. From the identification of students in the class of 20 students, it was found that five students still needed specific direction and assistance regarding neurosciencebased Arabic learning media. Neuroscience media adapted to what was expected by students and adapted to the way students learned by using the right brain and left brain, making learning easy and fun. This alternative learning strategy makes more use of learning media. ${ }^{16}$ Learning media are those whose material and content are related to brain function (Neuro-media). ${ }^{17}$

This research is based on the argument that students expect fun and easy learning to learn Arabic. Considering that, so far, participants at SMK Muhammadiyah 3 Yogyakarta have prioritized module-based learning or student worksheets and teacher textbooks. As evidenced by the findings obtained in preliminary research studies. This learning media is expected to be able to focus on the concentration of students in learning Arabic.

Many people distinguish between the terms media and props. However, those who use the two meanings interchangeably indicate the same tool or object (interchangeable). ${ }^{18}$ The difference between media and props lies in their function, not their substance. ${ }^{19} \mathrm{~A}$ learning resource is called a teaching aid if it is only called a media, it is an integral part of the entire learning process or activity and there is a kind of division of responsibilities between the teacher on the one hand and other sources (media) on the other. ${ }^{20}$ The word media comes from Latin which is the plural form of the word medium which means intermediary

${ }^{16}$ Mohammad Jailani, Suyadi Suyadi, and Muallimah Muallimah, "Development of AlQuran Hadith Learning with Ibn Sina's Leveled Intellectual Approach at SMK Muhammadiyah 3 Yogyakarta Based on Neuroscience: During the Covid-19 Pandemic," SALAM: Social and Cultural Journal Syar-I 8, no. 4 (2021): 1051-66, doi:10.15408/sjsbs.v8i4.18995.

${ }^{17}$ Mohammad Jailani, Suyadi, and Betty Mauli Rosa Bustam, "The First HISPISI's International Conference on Humanities, Education, Law , and Social Sciences ' New Findings during Pandemic in Social Science, Humanities , Education and Law ,'” in Neuroscience Based Islamic Learning a Critique of the Holistic Education Crisis in Pamekasan Madura, ed. Professor James A. Banks et al. (Jakarta: Jakarta State University, 2021), 123-34.

${ }^{18}$ Isnaini and Huda, "Development of Arabic Vocabulary Learning Media Based on My Happy Route Game."

${ }_{19}$ Rini and Partomuan Harahap, "Designing the Holistic Evaluation in Teaching Reading," Arabiyatuna: Arabic Journal5, no. 1 (2021): 141-60.

${ }^{20}$ Isnaini and Huda, "Development of Arabic Vocabulary Learning Media Based on My Happy Route Game." 
or introduction. In Arabic, the word media or intermediary has termed wasa'ala as the plural form of wasilatan. ${ }^{21}$

According to Isnaini and Huda, as explained in their article entitled Development of Arabic Vocabulary Learning Media based on the My Happy Route Game, media is a learning tool that is used to deliver learning materials. ${ }^{22}$ Media can be visual, such as cards containing pictures. ${ }^{23}$ There are also audiovisual media, such as learning videos, films, and so on. In addition, the media can also be in the form of audio, such as radio, cassette tapes, and so on. Maqfirlana, Sunismi, and Fathani stated that in conditioning a relaxed language class and informants, language learning media were needed. ${ }^{24}$

Meanwhile, Arabic is one of the official languages used in international relations, especially at meetings, assemblies, documents of the United Nations (UN), or other organizations. ${ }^{25}$ Therefore, the mastery of Arabic is very important for the world community and is not only limited to its use for religious purposes. ${ }^{26}$ Arabic is the major language in the world spoken by more than 200 million people. ${ }^{27}$ This language is officially spoken by approximately 22 countries in the world. ${ }^{28}$ Because it is included in the language of the holy book and the religious guidance of Muslims around the world, it means that it is very much needed by all mankind in the world, including the language of the Qur'an. $^{29}$

${ }^{21}$ Fithrotul Jannah et al., "Development of Arabic Language Program Towards Global Competition (Case Study at TAZKIA International Islamic Boarding School)," At-Ta'dib Journal 13, no. 2 (2018): 1-16.

${ }^{22}$ Isnaini and Huda, "Development of Arabic Vocabulary Learning Media Based on My Happy Route Game."

${ }^{23}$ Wissam Antoun, Fady Baly, and Hazem Haji, "Proceedings of the 4th Workshop on Open-Source Arabic Corpora and Processing Tools," in AraBert: Transformer-Based Model for Arabic Language Understanding, 2020, 9-15, http://arxiv .org/abs/2003.00104.

${ }^{24}$ Laila Sari Maqfirlana, Sunismi, and Abdul Halim Fathani, "Reflective Thinking and Mathematical Communication Skills Through Neuroscience-Based Jucama Model Assisted by Animiz Software for Class VII Materials," Journal of Research, Education, and Learning 14, no. 7 (2019): 57-68.

${ }^{25}$ Endang Switri, Zaimuddin, and Apriyanti, "Manhaji Method in Arabic Language Learning in Nursing, Faculty of Medicine," Lughoti 2, no. 01 (2020): 1-25.

${ }_{26}$ Muhammad Syifa'ul Qolbi et al., "Design and Development of Game Based Learning Applications for Mathematics Learning Based on Multiple Languages to Develop Verbal Capabilities," JPP (Journal of Education and Learning) 26, no. 2 (2019): 51-56, doi:10.17977/um047v26i22019p051.

${ }^{27}$ Switri, Zaimuddin, and Apriyanti, "Manhaji Method in Arabic Language Learning in Nursing, Faculty of Medicine."

${ }^{28}$ Ibid.

${ }^{29}$ Afifah Vinda Prananingrum, Ikhwan Nur Rois, and Anna Sholikhah, "Proceedings of the VI National Arabic Language Conference," in Theoretical Study of Arabic Learning Media (Malang: Department of Arabic Literature, Faculty of Letters, State University of Malang, 2020), 303-19. 
Discussing the Arabic language learning media juxtaposed with Neuroscience, basically this science is a science that studies the understanding of the brain and parts of the human brain. ${ }^{30}$ The main goal of Neuroscience is to study the biological underpinnings of every behavior. ${ }^{31}$ That is, the main task of Neuroscience is to explain human behavior from the point of view of the activities that occur in the brain. ${ }^{32}$ Recent research in the field of Neuroscience has found some evidence of an inseparable relationship between the brain and human behavior (character). ${ }^{33}$ Through the Positron Emission Tomography (PET) instrument, it is known that six brain systems integrated regulate all human behavior. The six brain systems are the prefrontal cortex, limbic system, cingulate gyrus, basal ganglia, temporal lobes, and cerebrum. ${ }^{34}$ Just as an example of researchers from Neuroscience studies to be specific and directed by researchers in Neuroscience, students are directed and trained in the right brain, left brain, and midbrain approaches. ${ }^{35}$ To easily understand the right brain and left brain, the researchers describe them in the image below:

${ }^{30}$ Hendro Widodo, "Development of Respect Education through Religious Humanist Education in Schools," Lentera Pendidikan: Journal of Tarbiyah and Teacher Training21, no. 1 (2018): 110-22, doi:10.24252/lp.2018v21n1i10.

31 Suyadi, "A Genealogycal Study of Islamic Education Science at The Faculty of Tarbiyah and Teacher Training UIN Sunan Kalijaga," Al-Jami'ab: Journal of Islamic Studies56, no. 1 (2018): 28-95, https://doi.org/10.14421/ajis.

${ }^{32}$ Taufiq Pasiak, "The word 'reason' was chosen as the key word to trace the traces of neuroscience in Islamic education thought" (UIN Alauddin, 2002).

33 Suyadi, Islamic Education and Neuroscience: Tracing the Traces of Reason and Brain in the Qur'an to the Development of Neuroscience in Islamic Education, ed. Lintang Novita, First (Jakarta: Kencana, 2020), www.Prenamedia.com.

34 Wikanti Iffah Juliani, Addinia Rizki Sabili, and Suyadi, "The Interpretation of Neuroscience Verses and Their Implications for the Development of Higher Order Thinking (HOT) in Islamic Education," Muaddib 10, no. 01 (2020): 84-96.

${ }^{35}$ Suyadi, Islamic Education and Neuroscience: Tracing Traces of Reason and Brain in the Qur'an to the Development of Neuroscience in Islamic Education. 


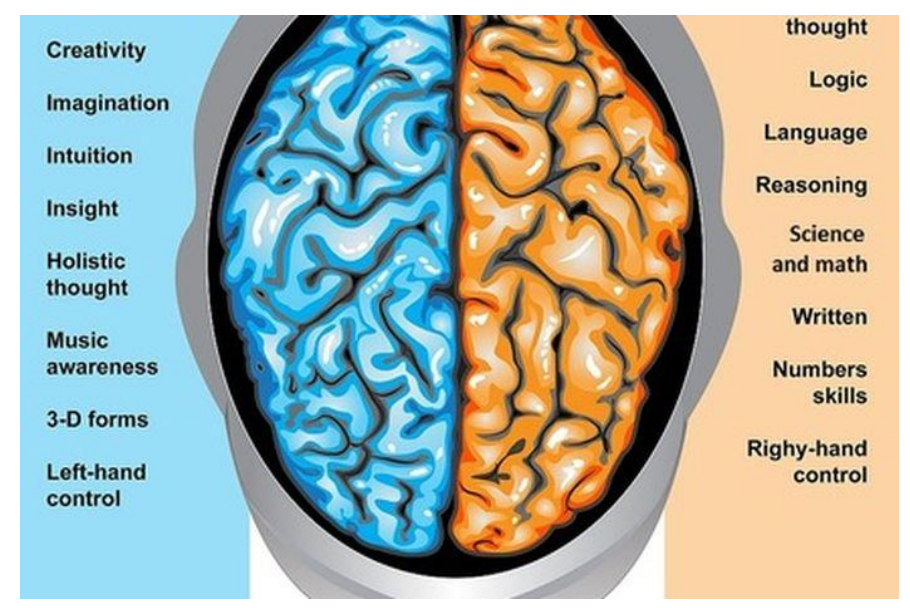

Figure 1. Right and left brain. ${ }^{36}$

Suyadi, as an expert in Neuroscience and Islamic Education, stated in his book, titled Islamic Education and Neuroscientists Tracing the Traces of Intellect and Brain in the Qur'an to the Development of Neuroscience in Islamic Education, that it is the left brain which is more active (but this does not mean that the right brain is passive). ${ }^{37}$ For example, when a person enters the mosque using his right foot, the left brain is more active.

Based on some of the terms above, neuroscience-based Arabic learning media is a learning medium used in delivering Arabic language material both in terms of mufrodat and mubadasah. The material is easy to understand in a way that students learn to memorize mufrodat and apply mubadasah. This is the learning media supported by procedural, operating procedures, and interesting audiovisuals. However, in this media, students are directed and focused on the approach of the brain, stimulating the right brain and left brain, in receiving the material delivered through the media. The teacher accompanies and directs students in understanding the learning material.

In line with that, a learning model with a brain approach already exists which is called a brain-based learning model. Brain-based learning is a learning model that has a relationship with the brain. This learning approach has been widely used by educators or researchers to apply or research on a research basis. ${ }^{38}$ Therefore, researchers seek to collaborate with brain-based learning

${ }^{36}$ Moh Asyihad Habib, "Write this down!! Difference Between Right Brain and Left Brain," Intisari Online, 2017, https://intisari.grid.id/read/0397022/cat-inilah-beda-sedalamnyaantara-otak-kanan-dan-otak-kiri?page $=$ all.

${ }^{37}$ Suyadi, Islamic Education and Neuroscience: Tracing Traces of Reason and Brain in the Qur'an to the Development of Neuroscience in Islamic Education.

38 Abu Bakr Siddiq, "The Application of «Nemo»Artificial Intelligence in Arabic Language Learning in the 4.0 Revolution Era At Al-Khalifah Islamic Boarding School Cibubur," 
whose derivatives are derived from learning media. ${ }^{39}$ In this case, the researcher focuses on neuroscience-based Arabic learning media. ${ }^{40}$

The research approach used in this study was qualitative. The reason for using this method was because it paves the way for understanding and describing the implementation of Arabic learning media at SMK Muhammadiyah 3 Yogyakarta. In this study, the research subjects were three teachers and twenty students. From the two categories of research subjects, it was expected to obtain complete data on neuroscience-based Arabic learning media in understanding, memorizing, and practicing Arabic mufrodat and mubadasah. Determination of research subjects was done by sampling data sources with certain considerations. Certain considerations, for example, the individuals involved as the subjects were those considered to know best about what we expected.

Data collection techniques were carried out using interview, observation, and documentation methods. First, in-depth interviews were guided by the interview protocol and were unstructured. Interviews became the primary technique of data collection in this study. The interviews were intended to obtain data by asking the informants questions about everything regarding neuroscience-based Arabic learning media in understanding, memorizing, and practicing Arabic language mufrodat and mubadasah at SMK Muhammadiyah 3 Yogyakarta. The informants to be interviewed were teachers and students. Second, observation was conducted to obtain information about neurosciencebased Arabic learning media at SMK Muhammadiyah 3 Yogyakarta. Observations were carried out in both formal or informal ways. Third, This study conducted documentation. The documents to be studied were texts and photos of Arabic learning media in SMK Muhammadiyah 3 Yogyakarta. The texts were in the form of learning modules, student worksheets, teacher administration, and learning curricula related to Arabic learning media. Meanwhile, the photos and recording documents provided visual information about the practical activities of neuroscience-based Arabic learning media at SMK Muhammadiyah 3 Yogyakarta.

Ijlecr - International Journal of Language Education and Culture Review 6, no. 1 (2020): 58-61, doi:10.21009/ijlecr.061.07.

${ }^{39}$ Wildana Wargadinata et al., "Arabic Creative and Participative Learning: In Search of a New Way of Language Learning by 'El Jidal Reborn' Youth Community in Malang," International Journal of Advanced Science and Technology Vol. 2, no. No. 8s (2020): 4319-32, doi:10.35542/osf.io/54yr9.

40 Suyadi, Zalik Nuryana, and Niki Alma Febriana Fauzi, "The Fiqh of Disaster: The Mitigation of Covid-19 in the Perspective of Islamic Education-Neuroscience," International Journal of Disaster Risk Reduction 51, no. 2 (2020): 1-15, doi:doi.org/10/1016/J.ijdrr.2020.101848. 
In this study, the type of data analysis used the Miles and Huberman (1994) model, namely the activities in qualitative data analysis were carried out interactively and took place continuously until complete so that the data were saturated. Activities in data analysis were data reduction, data display, and conclusion drawing/verification data. Three main interrelated activities occurred simultaneously, namely: data reduction, data display, and conclusion drawing or data verification.

\section{Results and Discussion}

The results of this study are presented based on the themes generated during the research process to collect data at SMK Muhammadiyah 3 Yogyakarta as well as to answer the problem formulation variables for the questions above. Based on the data analysis, it was found several main theme substances that influenced the results of this study, as can be viewed below:

\section{Implementation of Arabic Learning Media}

Researchers took research samples in class X (ten) TKJ 3. There were 20 students as in line with the preliminary study questionnaire. Regarding the implementation of neuroscience-based Arabic learning media at SMK Muhammadiyah 3 Yogyakarta. namely adjusting the material in the chapter on Arabic subjects. The material that had previously been conceptualized as best as possible by the teacher, adjusted the basic competencies and learning indicators. Learning materials are sourced from Arabic books that are relevant to learning Arabic, one of which is an Arabic book published by the Directorate General of Primary and Secondary Education for Muhammadiyah Regional Leadership in Yogyakarta City. Arabic Learning Media that has been packaged is very attractive with good audio-visual modifications.

Furthermore, the media is conveyed to students, and students are directed to focus on listening and understanding the material conveyed by the learning media. Learning media contains mufrodat and a series of sentences mubadasab which students will practice with their classmates. To mufrodat in the learning media contains five mufrodat which students will be asked and trained to read and memorize mufrodat. It is undeniable that some students cannot read yetlafadzArabic, some students are also able to read lafadz Arabic. According to the preliminary study, 50\% of students are still weak in reading the Qur'an and related things lafadz Arabic at SMK Muhammadiyah 3 Yogyakarta. Considering that because of the majority of students at SMK Muhammadiyah 3 Yogyakarta, from public schools.

The teacher identifies and divides the students in the class according to their capabilities of reading and memorizing lafadz and mufrodat. Students who already understand and can memorize are asked to help their friends who cannot read. The students were then asked to read together by the teacher, both those who could read and those who could not. Here's the material concerning mufrodat in learning media: 
Figure a.

\begin{tabular}{|c|c|}
\hline TERJEMAHAN/ARTI & TEKS ARAB \\
\hline Nama saya Mahmud & إسنْمِيْ مَحْمَدْ \\
\hline Saya seorang muslim & أَنَا مُسنْلِمٍ \\
\hline Saya punya keluarga yang besar & لِيْ أَسْرَةُ كَبِيْرَةٌ \\
\hline $\begin{array}{l}\text { Yaitu, ayah, ibu, saudara (lk), saudara (pr), kakek, dan } \\
\text { nenek }\end{array}$ & 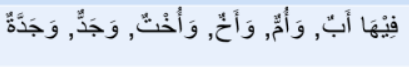 \\
\hline Ini ayahku & هـذا أَبيْ \\
\hline Namanya Ahmad & إسنْمُهُ أَحْمَدُ \\
\hline Dia guru di sekolah & هُوَ مُدَرَستُ فِي الْمَدْرَسَةِ \\
\hline Dan ini ibuku & وَهَذِهِ أَتِيَ \\
\hline Namanya Hamidah & إِنْمُهَا حَامِدةُّ \\
\hline Dia sorang ibu rumah tangga & هِيَ رُبَّةُ الَْبِيْتِ \\
\hline
\end{tabular}

Figure $b$

\begin{tabular}{|c|c|}
\hline TERJEMAHAN/ARTI & TEKS ARAB \\
\hline Dia cantik & هِيَ جَمِينَلَةُ \\
\hline Dia di dapur dengan nenekku & هِيَ فِي الْمَطْبَخ مَعَع جَدَّتِيْ \\
\hline Di dapur ada piring dan gelas & فِي الْمَطُبَخْ صَحْنٌ وَكُوَبْ \\
\hline Dan itu saudara (Ik) ku & وَذَلِلَكَ أَخْيْ \\
\hline Namanya Kholid & إسنمُهُ خَالِدٌ \\
\hline Dia di masjid & هُوَ فِي الْمَنْجِدِ \\
\hline Masjid di depan rumah & الْمَسنجِدُ أَمَامَ الْبَيْتِ \\
\hline Dan itu saudariku & وَتَلْلَك أخْتِيْ \\
\hline Namanya Laila & 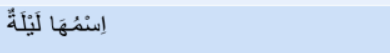 \\
\hline Dia seorang siswi & هِيَ تِلْمِيْذَة \\
\hline
\end{tabular}

Figure c.

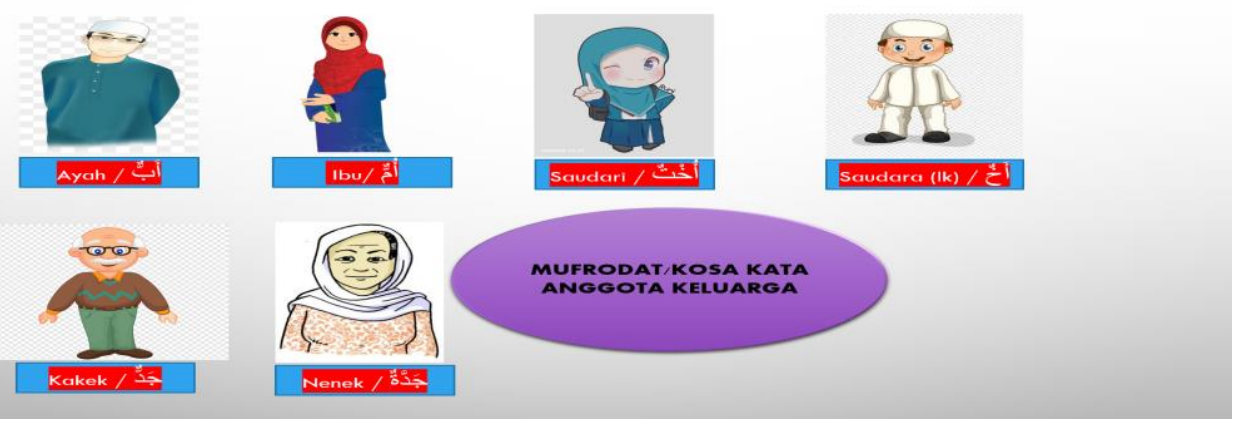

Figure 2, Arabic mufrodat 
The pictures above are the materials taught to students, consisting of Arabic text and its translation, about where to live in everyday life. The materials above are packaged with very interesting audio-visuals, which are delivered to students through interesting audio-visual videos.

Furthermore, students are trained to practice with their seatmates, to practice mubadasab in learning media. In this case, students can learn independently at home, but there is still mentoring and guidance from the teacher. This reinforcement in learning media leads to the approach of the student's brain, students are trained to focus on responding to their brain. As the available information is obtained by the teacher, students have only been directed to the learning module. Students are only guided by conventional technical explanations. This means that students are only lectured and told to pursue questions that have been explained by the teacher. As in the following picture:

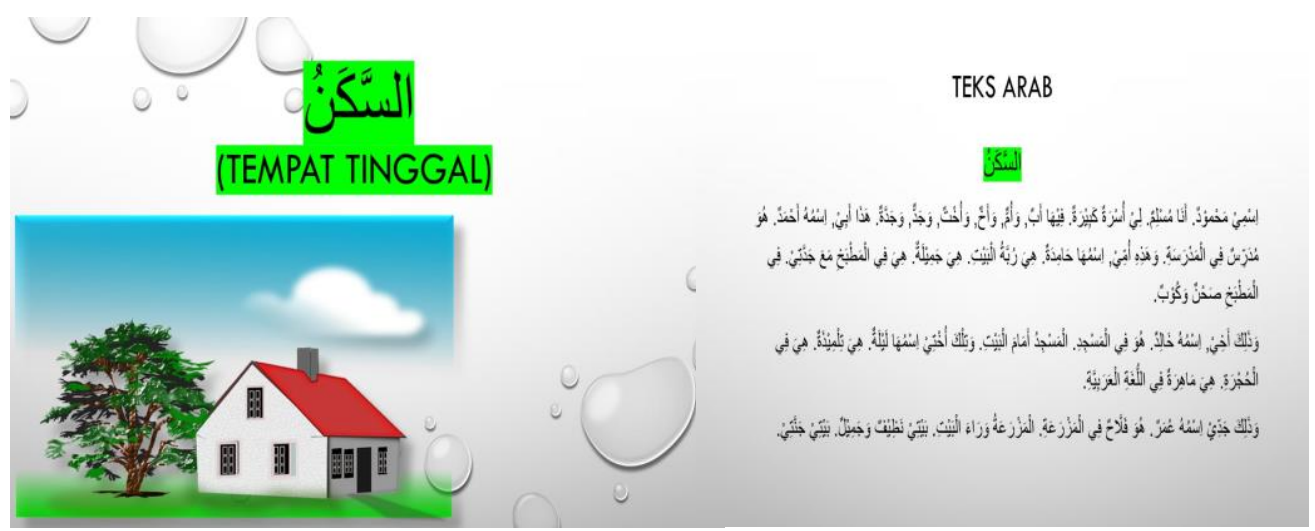

Image: 3. Arabic Mubadasah

The description of the material above is a lesson delivered by the teacher to the students. The chapter on residence (assyakanu). Students are taught about maharah qiro'ah good reading, maharah istima' good listening, maharah kitabah writing correctly and $i m l a$, and finally, they are expected to be able to practice by speaking maharah kalam. Of course, in this media, the teacher acts as a facilitator and makes it easier for students to learn Arabic.

As for the mabarah qiro'ah students with neuroscience-based learning media direct students to be trained in reading Arabic words and sentences. Mastering and understanding the bijaiyah letters and directed to learn to read Arabic correctly. So that later it is easy to memorize and say mufrodat or Arabic lafad₹. For maharah kitabah students are guided and taught in learning to write Arabic words and sentences with imla'. Learned to connect Arabic script correctly. Furthermore, related to maharah istima' students are directed to listen to Arabic words and sentences correctly. The existence of learning media helps 
students more easily listen to Arabic sentences. Because in the media, there are audio-visuals that have been packaged well. Finally, maharah kalam students are targeted to be able to speak Arabic, at least students can convey Arabic words and sentences by Arabic mufrodat material. The final result is that students practice with their friends both in the school environment and at home.

Thus, the Arabic language learning media can make it easier for students to understand the material both mufrodat or quwaidul arobiyah in applying mubadasah practices in everyday life. Learning media focuses on directing students with a neuroscience approach to students' brains. Arabic learning runs smoothly and by the learning targets. Even though at this time the covid-19 pandemic, learning media can be operated and studied at each student's home. The steps of neuroscience-based Arabic learning media are as follows:

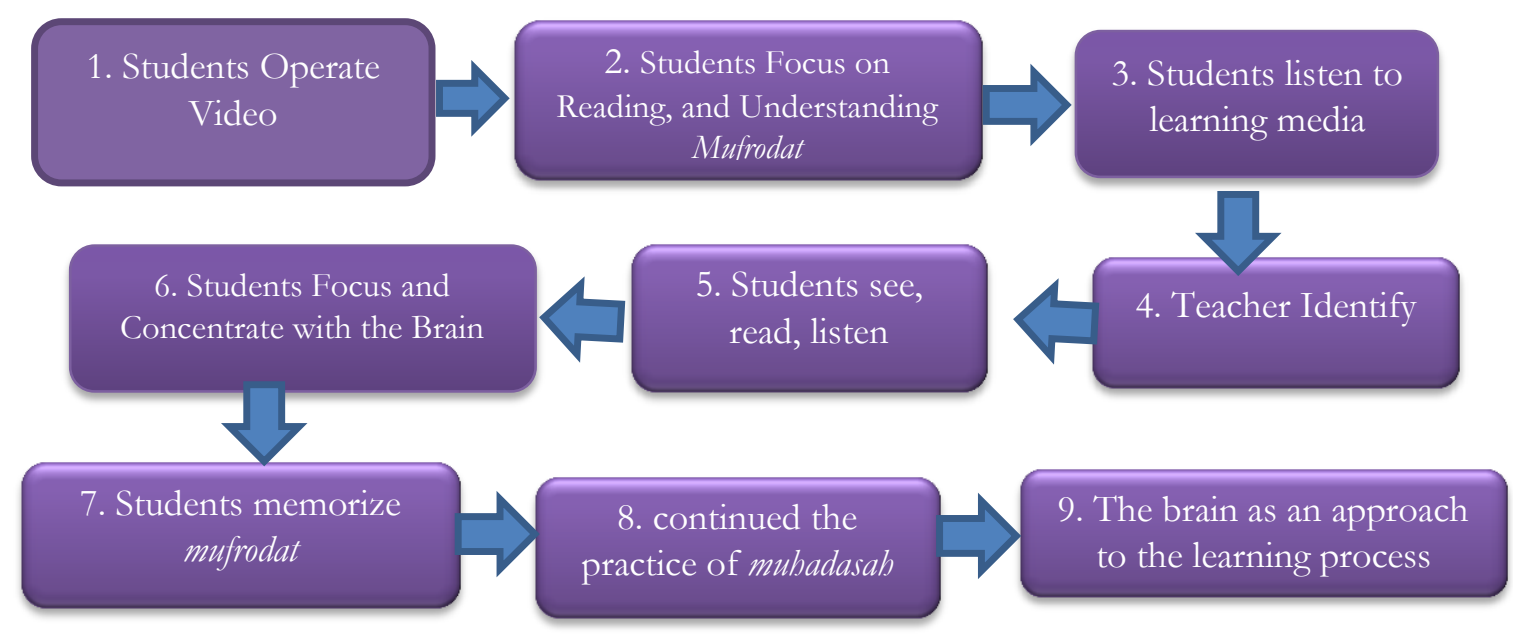

Figure 4. The flow of learning media steps.

The steps in neuroscience-based Arabic learning media as follows:

1. Students operate audio-visual videos that have been given (shared) by the teacher.

2. Students see the readings delivered by the teacher in the media

3. Students listen well to the audio-visual material mufrodat and mubadasah

4. Students concentrate on the brain and respond to the language to be spoken

5. Students see, read, listen, and practice what the teacher says in the media.

6. The teacher identifies students who cannot read and students who can read Arabic mufrodat.

7. Students are directed to memorize five mufrodat and asked to practice saying them, according to the material mufrodat.

8. The students continued to practice mubadasab with their classmates.

9. Right brain and left brain as approaches in learning Arabic, neurosciencebased Arabic learning media 


\section{Arabic Learning Media Material Content}

With respect to the material presented in Arabic learning with the theme "as-sakan", there are several strategies and methods applied by educators in delivering material in Arabic learning media. The learning materials are as follows:

The contents of the materials in the learning media include:

1. Mufrodat

Educators are directed to be able to practice vocabulary related to khiwar or as-sakanu

In this chapter, discourses and conversations about as-sakanu will be described. Students with this theme are expected to be able to recognize some expressions and as-sakanu in Arabic.

Among them are about syahsun, ikhwatun, syifatun, wasyilatun, alqobailu, assy'ubu al'mujtamau, alusrotu.

Followed by student practice, which includes reading, writing, and listening, the final result of the material is the practice of conversation about the introduction.

2. Learn Arabic listening strategies (istima')

In this strategy, an example of an Arabic conversation will be provided which will be examined at the end, including correction by the educator, regarding the Arabic text and its translation.

In listening, students focus and adjust the material presented with concentration and focus. Learning videos that are displayed by visualizing interesting pictures or acting conversations in the video or media.

3. Arabic learning strategies for writing books

hijaiyah letters that cannot be written together.

Writing materials for students to learn to write well.

4. Strategies for learning to read Arabic (qiroab)

In this strategy, students are directed to read well, read Arabic learning materials about as-sakanu

5. Strategies for learning to speak Arabic (kalam)

In this strategy, students create conversations or short stories about their daily lives at home with their families to practice Arabic pronunciation.

\section{Implications of Neuroscience-Based Arabic Learning Media}

Based on research findings and research data related to learning in SMK Muhammadiyah 3 Yogyakarta, especially in learning Arabic, media-based learning with the Neuroscience approach colors the teaching and learning process objectively. Together with the researcher's findings and the results of observations and interviews at SMK Muhammadiyah 3 Yogyakarta, the researchers in this case, are more directed to students by putting forward neuroscience-based Arabic learning media. Such media make it easier for 
students to learn Arabic which has been considered very difficult and boring, especially in mufrodat, mubadasah, and quwaid material. By the results of the implementation of the use in the classroom, of 20 students in class, only five people have not responded well. However, in this case, special guidance and assistance are needed in schools. For example, special tutoring is included, extracurricular learning Arabic, and the presence of an accompanying Arabic teacher. Considering that the learning media as a facilitator in learning Arabic is adjusted to the role of Neuroscience in the thinking ability of students. Adjusting the way students learn with their brain development in cognitive, affective, and psychometric.

Previously, the Arabic learning held by teachers used conventional methods or lecture techniques. This makes students feel that there has been no progress related to learning Arabic. Discussing the Arabic language learning media juxtaposed with Neuroscience, basically this science is a science that studies the understanding of the brain and parts of the human brain.

Thus, the Arabic language learning media will facilitate the learning of Arabic at SMK Muhammadiyah 3 Yogyakarta based on neuroscience, followed by the results of the researchers' preliminary study as follows:

\section{Figure a.}

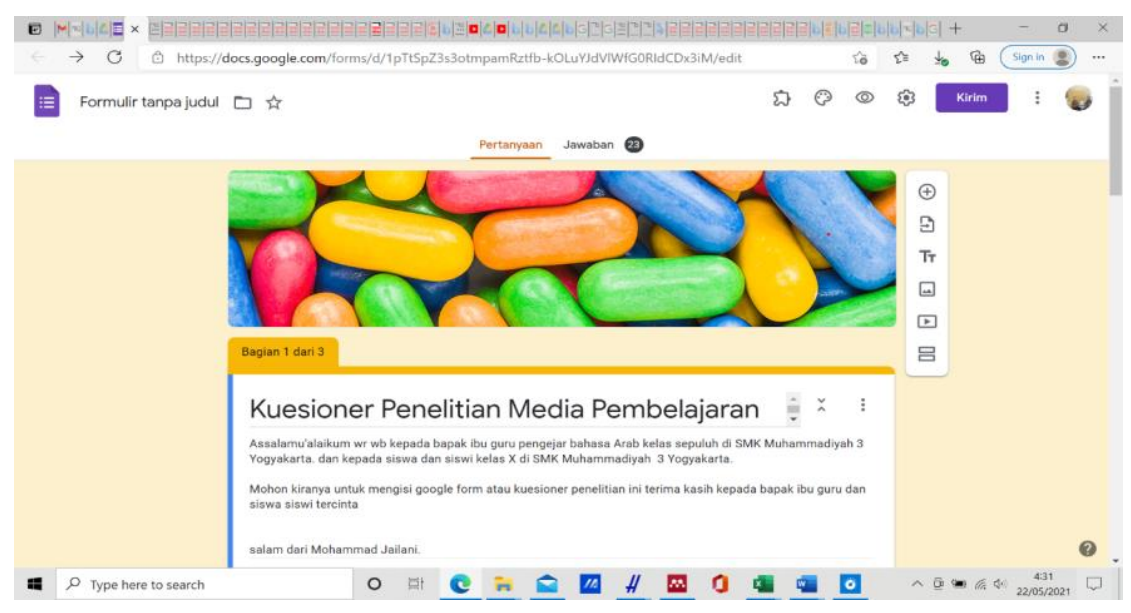




\section{Figure $b$.}

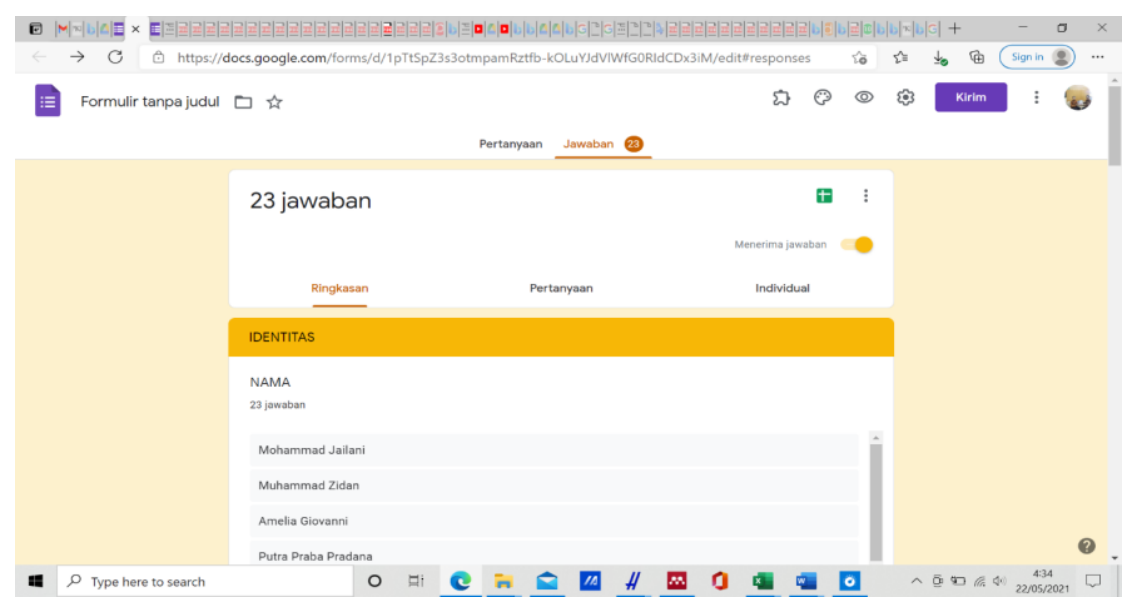

Figure 5. Findings of the Preliminary Study of Learning Media.

Considering that learning media is also growing rapidly, Arabic-based learning media emerged in neuroscience. Neuroscience as a facilitator to link students' interest in language learning. The power of thinking that is focused and happy, affects the brain. Related to that, the part of the brain that responds to the task of developing information and optimizing the brain is the prefrontal cortex. This part serves to send brain nerve cells to the right brain and left brain.

The media is delivered to students, with material that contains small examples of mubadasab and mufrodat learning. Learning Arabic, cannot be separated from the material, because the material is at the core of learning Arabic or is listed in the basic competencies of learning Arabic. Educators convey to students by mubadasah or grammar material (quwaid). In this chapter students are trained in the skills of reading, writing, listening, and most importantly speaking (muhadasah). Thus learning helps into the substance of the material delivered in large or small Arabic learning, for example, as an innovation in the 4.0 revolution era. (Melineal era).

Based on the results of research at SMK Muhammadiyah 3 Yogyakarta, researchers tabulated students who could respond to and understand Arabic learning on mubadasah, quwaidul 'arobiyah material including kitabah, qiro'ah, istima', and kalam, using Neurosians-based Arabic learning media, as shown in the table below:

Table 1. Sample of Learners Familiar with Arabic Language Subjects

\begin{tabular}{llcr}
\hline No & \multicolumn{2}{c}{ TKJ Department Class X TKJ 1 } & \multicolumn{2}{c}{ Result/ Understand } \\
& & Male & female \\
\hline 1 & Muhammad Zidane & understand & \\
2 & Amelia Giovani & & understand \\
3 & Praba Pradana's son & understand &
\end{tabular}




\begin{tabular}{|c|c|c|c|}
\hline 4 & Sita Maharani & & understand \\
\hline 5 & Haninda Shafa Dhiani & & understand \\
\hline 6 & Sarah Jasmine & & understand \\
\hline 7 & Dava Maulana Yusuf & & understand \\
\hline 8 & Rhea Unikha Harist & & understand \\
\hline 9 & Yudanta Azhari Pranajaya & understand & \\
\hline 10 & Muhammad Wahid Setiawan & & understand \\
\hline 11 & Yanu Dwi Danuarta & understand & \\
\hline 12 & Rafli Andika P & understand & \\
\hline 13 & Abid Al-Muqarrabun & understand & \\
\hline 14 & Nugroho Dwi Maryanto & understand & \\
\hline 15 & Dzakwan Ali Ridhawi & understand & \\
\hline 16 & Amen Traveler & understand & \\
\hline 17 & Daffa Alif Muhammad & understand & \\
\hline 18 & Khayla Najwa Almira & & understand \\
\hline 19 & Muhammad Frisqi Abuwardhana & understand & \\
\hline 20 & Muhammad Tariq Bin ziad & understand & \\
\hline
\end{tabular}

Based on the results of the tabulation of students above, it explains that students better understand Arabic learning or the teaching and learning process in the classroom. Responding to the easy practice of mubadasab because researchers are more directing students in mubadasah material by adjusting their brain development abilities. ${ }^{41}$ Hence, out of 20 students in class X (ten) TKJ 1, some students are still weak in memorizing mufrodat material, from the fact that students can understand and follow the learning and so on. Thus, the trial of the Neuroscience-based Arabic learning model helps make it easier for students to learn Arabic.

\section{Conclusion}

Based on the results of research and discussion, it turns out that the development of Arabic learning media can work in the world of Arabic language education, especially under the auspices of Islamic Education and the Arabic language family. In coloring learning at SMK Muhammadiyah 3 Yogyakarta, which incidentally is more practice than theory. Arabic learning directed at Arabic learning media makes it easier for students to learn to read, write and speak, especially students can practice muhadasah and quwaidul lugeh al-'arobiyah even though learning is online or online. Arabic learning media contains very interesting material content in the form of audio-visuals supported by learning methods that attract students' sympathy. The second, with the Neuroscience approach or Neuroscience-based Arabic learning media, adjust students' Arabic language abilities in affective, cognitive, and psychomotor aspects because

\footnotetext{
${ }^{41}$ Homeroom, Research Questionnaire for Preliminary Study of Arabic Learning (2021).
} 
students no longer have difficulty learning Arabic. Based on the results of the research in the tabulation and questionnaire above, 80 percent of students were able to understand the process of running the material well. As well as students who respond to Arabic learning media, 20 students expect that at SMK Muhmamadiyah 3 Yogyakarta, learning is needed with a media-based learning model. Given this, the importance of Arabic learning media is very important in teaching and learning at SMK Muhammadiyah 3 Yogyakarta which is an Islamic and vocational base school.

As ordinary humans, researchers also have shortcomings, as well as in this study, it has limitations both in content and analysis of the main substance in this study, just an example, researchers have not discussed the current form of neuroscience media output, only leading to approaches, neuroscience perspectives in learning media. Specifically, there is still no data and the relevance of the relevant theory, of course, still not, the two researchers have not linked it to learning problems during the Covid-19 period, which is happening to Arabic language learning in schools. In the interdisciplinary, transdisciplinary, and multidisciplinary linkages in the Arabic language education discourse.

Researchers recommend to (academics and researchers) to do further research to find a comprehensive Arabic learning model, just an example of an interpretation-based Arabic learning media that all materials are related to the verses of the Qur'an to bring students closer to the Qur'an. 'an or Ibn Sina's multilevel reasoning approach, because the researcher realizes that there are no researchers who lead the research base. Research that has broad implications for the Arabic language learning discourse in the Covid-19 era and in modern times.

\section{Bibliography}

Abu Bakar Shiddiq. “The Application of «Nemo» Artificial Intelegence in Arabic Language Learning in the 4.0 Revolution Era At Al- Khalifah Islamic Boarding School Cibubur." Ijlecr - International Journal of Language Education and Culture Review 6, no. 1 (2020): 58-61. doi:10.21009/ijlecr.061.07.

Antoun, Wissam, Fady Baly, and Hazem Hajj. "Proceedings of the 4th Workshop on Open-Source Arabic Corpora and Processing Tools." In AraBert: Transformer-Based Model for Arabic Language Understanding, 9-15, 2020. http://arxiv.org/abs/2003.00104.

Arifa, Zakiyah, and Dewi Chamidah. "Pengembangan Bahan Ajar Qawaid Bahasa Arab Berbasis Mid Map Untuk Tingkat Perguruan Tinggi." The International Journal of Artificial Organs 10, no. 6 (1987): 406-7. doi:10.1177/039139888701000618.

Fauzi Muhammad Ilfan. "Pemanfaan Neurosains Dalam Desain Pengembangan Kurikulum Bahasa Arab." Arabiyatuna: Jurnal Bahasa Arab 4, no. 1 (2020): 1. doi:10.29240/jba.v4i1.1095. 
Habib, Moh Asyihad. "Catat Inilah!! Perbedaan Antara Otak Kanan Dan Otak Kiri." Intisari Online, 2017. https://intisari.grid.id/read/0397022/catat-inilah-perbedaansebenarnya-antara-otak-kanan-dan-otak-kiri?page $=$ all.

Isnaini, Nurul, and Nurul Huda. "Pengembangan Media Pembelajaran Kosakata Bahasa Arab Berbasis Permainan My Happy Route.” Al Mi'yar: Jurnal Ilmiah Pembelajaran Bahasa Arab Dan Kebahasaaraban 3, no. 1 (2020): 1. doi:10.35931/am.v3i1.156.

Jailani, Mohammad, Suyadi, and Betty Mauli Rosa Bustam. "Edisi Khas: Pengajian Islam Dan Cabaran Pandemi COVID-19." In Perkembangan Media Pembelajaran Bahasa Arab Berasis Neurosains: Kajian Lapangan Di Sekolah Menengah Kejuruan Di Masa Covid-19, edited by Rohana Zakaria, Safinah Ismail, Mariam Mat Daud, and Syed Mohamad Zainuddin Bichk Koyak, 44-50. Malaysia: Kolej Universitas Islam Antarbangngsa Selangor (KUIS), 2021.

Jailani, Mohammad, Suyadi, and Betty Mauli Rosa Bustam. "The First HISPISI' s International Conference on Humanities, Education, Law , and Social Sciences ‘ New Findings during Pandemic in Social Science, Humanities, Education and Law ." In Neuroscience Based Islamic Learning a Critique of the Holistic Education Crisis in Pamekasan Madura, edited by Professor James A. Banks, Professor Ian Davies, Professor Ying Huei Chen, Professor Zakiyuddin Baidhawy, Associate Professor Bulent Tarman, and Associate Professor Dr. Zulhamri Abdullah, 123-34. Jakarta: Universitas Negeri Jakarta, 2021.

Jailani, Mohammad, Suyadi, and Dedi Djabedi. "Menelusuri Jejak Otak Dan 'Aql Dalam Al-Qur'an Perspektif Neurosains Dan Pendidikan Islam Di Era Pandemi COVID-19." Tadris: Jurnal Pendidikan Islam 16, no. 1 (2021): 1-19. doi:10.19105/tjpi.v16i1.4347.

Jailani, Mohammad, Suyadi Suyadi, and Muallimah Muallimah. "Pengembangan Pembelajaran Alquran Hadis Dengan Pendekatan Akal Bertingkat Ibnu Sina Di SMK Muhammadiyah 3 Yogyakarta Berbasis Neurosains: Di Masa Pandemi Covid-19." SALAM: Jurnal Sosial Dan Budaya Syar-I 8, no. 4 (2021): 1051-66. doi:10.15408/sjsbs.v8i4.18995.

Jailani, Mohammad, Wantini, Suyadi, and Betty Mauli Rosa Bustam. "Meneguhkan Pendekatan Neurolinguistik Dalam Pembelajaran: Studi Kasus Pada Pembelajaran Bahasa Arab Madrasah Aliyah." Al-Thariqah Jurnal Pendidikan Islam 6, no. 1 (2021): 152-67.

Jailani, Mohammad, Hendro Widodo, Siti Fatimah, Fakultas Agama Islam, Magister Pendidikan, Agama Islam, Universitas Ahmad Dahlan, et al. "Pengembangan Materi Pembelajaran Pendidikan Agama Islam: Implikasinya Terhadap Pendidikan Islam." Al-Idarah: Jurnal Kependidikan Islam 11, no. 1 (2021): 143-55.

Jannah, Fithrotul, Rikza Yuniasti, Khawil Ma'ali, and Zakiyah Arifa. "Pengembangan Program Bahasa Arab Menuju Persaingan Global ( Studi Kasus Di TAZKIA International Islamic Boarding School ).” Jurnal At-Ta'dib 13, no. 2 (2018): 1-16.

Juliani, Wikanti Iffah, Addinia Rizki Sabili, and Suyadi. “Tafsir Ayat-Ayat Neurosains Dan Implikasinya Bagi Pengembangan Higher Order Thingking (HOT) Dalam 
Pendidikan Islam.” Muaddib 10, no. 01 (2020): 84-96.

Kelas, Wali. Kuisioner Penelitian Studi Pendahuluan Pembelajaran Bahasa Arab (2021).

Khomsah, Ahmad Fadilah, and Muhammad Imron. "Pembelajaran Bahasa Arab Melalui Kolaborasi Metode Questioning Dan Media Kahoot.” Tarbiyatuna: Jurnal Pendidikan Ilmiah 5, no. 1 (2020): 99-118.

Kurniawan, Rahadian, Musda Asmara, and H Hardivizon. "Arabic Language and the Concept of I'jaz Al-Qur'an (Critics to Louwis 'Awad's Thoughts/Bahasa Arab Dan Konsep I'jaz Al-Qur'an (Kritik Pemikiran Louwis 'Awad).” Arabiyatuna: Jurnal Bahasa Arab 5, no. 1 (2021): 161. doi:10.29240/jba.v5i1.2622.

Maqfirlana, Laila Sari, Sunismi, and Abdul Halim Fathani. "Kemampuan Berpikir Reflektif Dan Komunikasi Matematis Melalui Model Jucama Berbasis Neurosains Berbantuan Software Animiz Materi Segiempat Kelas VII.” Jurnal Penelitian, Pendidikan, Dan Pembelajaran 14, no. 7 (2019): 57-68.

Mufidah, Nuril, Ulya Zahrotul Firdaus, Saidna Zulfiqar, and Bin Tahir. "Model Pengayaan Tutor Bahasa: Studi Pre-Learning Pada Shabahul Lughoh Di Ma'had Sunan Ampel Al Aly." At-Ta'dib 13, no. 2 (2018): 50-61. doi:10.21111/attadib.v13i2.2650.

Mufidah, Nuril, and Intan Izha Rohima. "Pengajaran Kosakata Untuk Mahasiswa Kelas Intensif Bahasa Arab (Vocabulary Teaching For Arabic Intensive Class)." (Ujss) Uniqbu Journal Of Social Sciences 5, no. 1 (2020): 55.

Prananingrum, Afifah Vinda, Ikhwan Nur Rois, and Anna Sholikhah. "Prosiding Konferensi Nasional Bahasa Arab VI." In Kajian Teoritis Media Pembelajaran Babasa Arab, 303-19. Malang: Jurusan Sastra Arab Fakultas Sastra Universitas Negeri Malang, 2020.

Qolbi, Muhammad Syifa'ul, Zahid Zufar At Thaariq, Sayyidati Fatimah Az-Zahroh, M Mahfudz Anwar, and Nurul Faiza. "Design and Development of Game Based Learning Applications for Mathematics Learning Based on Multiple Language to Develop Verbal Capabilities." JPP (Jurnal Pendidikan Dan Pembelajaran) 26, no. 2 (2019): 51-56. doi:10.17977/um047v26i22019p051.

Rini, and Partomuan Harahap. "Designing the Holistic Evaluation in Teaching Reading." Arabiyatuna: Jurnal Bahasa Arab 5, no. 1 (2021): 141-60.

Ritonga, Apri Wardana, Wildana Wargadinata, Mahyudin Ritonga, and Suci Ramadhani Febriani. "Teaching Maharah Kalam on the Basis of Culture Using the Textbook 'Al-,,Arabiyyah Baina Yadaik' at the Middle School.” Arabiyatuna: Jurnal Bahasa Arab 5, no. 1 (2021): 1-22.

Suyadi. "A Genealogycal Study of Islamic Education Science at The Faculty of Ilmu Tarbiyah Dan Keguruan UIN Sunan Kalijaga." Al-Jami" ah: Journal of Islamic Studies 56, no. 1 (2018): 28-95. https://doi.org/10.14421/ajis.

Suyadi. Pendidikan Islam Dan Neurosains: Menelusuri Jejak. Akal Dan Otak Dalam Alquran Hingga Pengembangan Neurosains Dalam Pendidikan Islam. Edited by Lintang Novita. Pertama. Jakarta: Kencana, 2020. www.Prenamedia.com. 
Suyadi, Zalik Nuryana, and Niki Alma Febriana Fauzi. "The Fiqh of Disaster: The Mitigation of Covid-19 in the Perspective of Islamic Education-Neuroscience." International Journal of Disaster Risk Reduction 51, no. 2 (2020): 1-15. doi:doi.org/10/1016/J.ijdrr.2020.101848.

Switri, Endang, Zaimuddin, and Apriyanti. "Metode Manhaji Pada Pembelajaran Bahasa Arab Di Ilmu Keperawatan Fakultas Kedokteran.” Lughoti 2, no. 01 (2020): 1-25.

Taufiq Pasiak. "Dipilih Kata 'Akal' Sebagai Kata Kunci Menelusuri Jejak Neurosains Dalam Pemikiran Pendidikan Islam.” UIN Alauddin, 2002.

Ummu Saidah, Saidna Zulfiqar Bin-Tahir, Nuril Mufidah. “Arabic Teachers' Competence: A Case of Madrasah Schools in Maluku.” Ijaz Arabi 1, no. 21 (2018): $1-9$.

Wargadinata, Wildana, Iffat Maimunah, Saidna Zulfiqar Bin Tahir, and M Chairul Basrun Umanailo. "Arabic Creative and Participative Learning: In Search of a New Way of Language Learning by 'El Jidal Reborn' Youth Community in Malang." International Journal of Advanced Science and Technology Vol. 2, no. No. 8s (2020): 4319-32. doi:10.35542/osf.io/54yr9.

Widodo, Hendro. "Pengembangan Respect Education Melalui Pendidikan Humanis Religius Di Sekolah." Lentera Pendidikan : Jurnal Ilmu Tarbiyah Dan Keguruan 21, no. 1 (2018): 110-22. doi:10.24252/lp.2018v21n1i10. 